\title{
Indonesia Sharia Bank Merger Process Reviewed from Business Competition Laws
}

\author{
Shahyb Handyanto \\ Faculty of Law, Universitas Gadjah Mada, Sleman, Yogyakarta, Indonesia \\ Email: shahybhandyanto@mail.ugm.ac.id \\ ORCID Link: https://orcid.org/0000-0001-6310-1544 \\ Monita Sri Astuti \\ Faculty of Law, Universitas Gadjah Mada, Sleman, Yogyakarta, Indonesia
}

Kevin Surya Ajiputra

Faculty of Law, Universitas Gadjah Mada, Sleman, Yogyakarta, Indonesia

\section{Citation:}

Handyanto, S., Astuti, M. S., \& Ajiputra, K. S. (2021). Indonesia Sharia Bank Merger Process Reviewed from Business Competition Laws, Lex Scientia Law Review, 5(1), 45-62, doi: https://doi.org/10.15294

/lesrev.v5i1.46288

\section{History of Article}

Received: April 21, 2021

Revised: May 17, 2021

Accepted: May 21, 2021

(C) The Author(s)

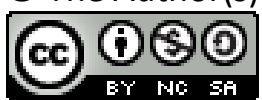

This work is licensed under a Creative Commons Attribution-NonCommercialShareAlike 4.0 International License. All writings published in this journal are personal views of the authors and do not represent the views of this journal and the author's affiliated institutions.

Lex Scientia Law Review published by Faculty of Law, Universitas Negeri Semarang, Indonesia in collaboration of UKM Lex Scientia. Published biannually every May and November.

\begin{abstract}
Islamic bank entities in Indonesia, namely BNI Syariah, BRI Syariah, and Bank Syariah Mandiri have merged to become Bank Syariah Indonesia. The merger process was effective on February 1, 2021. As we know, the three banks are state-owned, which have significant assets and have a reasonably large market in Indonesia. In connection with business competition law which seeks to create a fair business competition situation in Indonesia, every corporate action, including merger activities, must be notified to the Business Competition Supervision Commission (hereinafter as KPPU) to assess whether monopolistic practices or unfair business competition have occurred or not. The notification is an effort to supervise every business actor in order to carry out activities that do not violate business competition and do not harm other parties. This study aims to examine normatively the merger process carried out based on business competition law in Indonesia. The research uses materials from both regulations, legal principles, doctrine, and sources related to the subject matter. The data obtained were then analyzed for further analysis to produce conclusions. The results
\end{abstract}


showed that the merger process between the three Islamic banks in Indonesia did not violate the business competition law because it did not occur in a position monopoly and the absence of monopolistic practices.

\section{KEYWORDS}

Business Competition Law; Merger; Monopoly

\section{INTRODUCTION}

The concept of Islamic banking in Indonesia began to be known by the public at the birth of Muamalat Bank Indonesia in 1991, which became the first commercial bank to carry out its business activities with Islamic principles. According to Abdul Ghofur Anshori'Since 1992 the banking industry in Indonesia has started to recognize the term bank based on the profit-sharing principle. However, in practice, Islamic banks do not only carry out profit-sharing activities but also use other principles such as nonusury (without interest), non-garar (without interest), uncertainty element), non-maisyir (without the element of gambling), and without the element of vanity which is an element that is prohibited in Islam. Along the way, the development of Islamic banks is encouraged to provide and increase the resilience of the national economy. With a sharia banking system that is free of usury and without speculative character, in this case, it can create a resilient economy, namely an economy whose growth in the financial sector is in line with the growth of the real sector. ${ }^{2}$

The potential for the development of the Islamic banking industry in Indonesia is quite immense. It can be seen from the number of Muslims in Indonesia in 2020, based on the World Population Review, reaching 229 million or $87.2 \%$ of the total population of 273.5 million. ${ }^{3}$ This figure shows that the market share of the Islamic banking industry in Indonesia is quite promising. The current development of the Islamic banking industry can be seen in terms of the number of players in the Islamic banking industry, which has shown a pretty good development, marked by the number of Islamic

\footnotetext{
1 Abdul Ghofur Anshori, "Sejarah Perkembangan Hukum Perbankan Syariah di Indonesia dan Implikasinya Bagi Praktik Perbankan Nasional", Jurnal Hukum Islam La Riba, Volume 2 Number 2, 2008, p. 159-172.

2 Ali Syukron, "Dinamika Perkembangan Perbankan Syariah Di Indonesia", Jurnal Ekonomi dan Hukum Islam STAI Darul Ulum Banyuwangi, Volume 3 Number 2, 2013, p. 28-53.

${ }^{3}$ Kormen Barus, "Jumlah Penduduk Muslim Indonesia Meningkat, PowerCommerce Asia Tangkap Peluang, Luncurkan Halal Plaza", Industricoid, May 16, 2021, accessed from https://www.industry.co.id/read/65748/jum-penduduk-muslim-indonesia-menaikanpowercommerce-asia-tangkap-peluang-l Launch-halal-plaza.
} 
banks reaching 14 banks, 20 Sharia Business Units (UUS), and 162 Sharia Rural Banks (BPRS). ${ }^{4}$

At the beginning of 2021, there was an event that captured the attention of the public, which was related to the development of Islamic banking in Indonesia, namely the merger of three state-owned Islamic banks, namely BNI Syariah (BNIS), BRI Syariah (BRIS) and Bank Syariah Mandiri (BSM) which changed to Bank Syariah Indonesia (BSI). In its development, many views have emerged regarding the merger of the three banks, most of which believe that the merger event will harm Islamic banking in Indonesia.

In a journal by Nabilah Anika et al5In conclusion, it gives the view that the BSI merger process, when viewed from the existing potential, has the opportunity to dominate the Islamic banking industry and can lead to potential monopolistic practices. However, the view regarding the potential of this monopolistic practice needs to be studied further based on business competition law. As for determining whether or not monopolistic practices exist, the KPPU needs to measure or evaluate the BSI merger with a legal approach and an economic approach. The legal approach is intended to interpret the elements in monopolistic practices based on the provisions of business competition law, namely Law Number 5 of 1999 concerning the Prohibition of Monopoly Practices and Unfair Business Competition. Article related to monopolistic action in the quo Law is formulated with a rule of reason, which means that further proof is necessary if the business actor has fulfilled the elements of monopoly action, namely control over the use of Indonesian sharia banking services. Further evidence in the rule of reason approach is intended to determine whether the monopoly action taken will result in unfair business competition. In essence, in assessing the above views and several other views which state that the merger event will have an impact on the ongoing Islamic banking system in Indonesia, the following evidence must be made; (1) whether the merger of Bank Syariah Indonesia is a monopoly act, and (2) if there is a monopoly act.

\section{METHOD}

The type of research to be carried out is normative juridical research. Normative juridical research is a type of research that examines law as a

\footnotetext{
${ }^{4}$ OJK, Statistik Perbankan Syariah Desember 2020, Financial Services Authority, Jakarta, 2020, p. 5.

${ }^{5}$ Nabilah Anika, Nabila Indah Chairunnisa, \& Aditya Wahyu Saputro, "Potensi Praktik Monopoli Dalam Merger Bank Syariah Indonesia: Tinjauan Hukum Ekonomi Islam dan Hukum Larangan Monopoli", Rewang Rencang: Jurnal Hukum Lex Generalis, Volume 2 Number 2, 2021, p. 174-194.
} 
value, as a conceptual system, and as a positive legal system. ${ }^{6}$ In other words, it is studying law from an internal perspective, with the object being legal norms. ${ }^{7}$ The approach taken is the statue approach and the conceptual approach. The statute approach is carried out by examining various kinds of laws and regulations related to the topics discussed. At the same time, the conceptual approach is carried out by citing expert opinion, which can be used as material for analysis.

This study uses secondary data consisting of: a. primary legal materials consisting of basic norms or rules, introductory provisions or regulations, and statutory regulations; and b. secondary legal materials, which are legal materials, provide further explanation regarding primary legal materials, including literature, articles, journals, and research results. ${ }^{8}$ Then the legal materials were collected through document study to be further processed using descriptive-qualitative methods to answer the problems in this study.

\section{RESULT AND DISCUSSION}

\section{A. Indonesian Sharia Bank Merger Process}

Departing from the condition of sharia banking in Indonesia, as the National Sharia Finance Committee (hereinafter as KNKS) reviewed that there is a need for a government role (full intervention) to grow the Islamic banking industry in Indonesia, whose market share still revolves around 5\%, an option to Merge PT Bank BRISyariah Tbk. (BRIS), PT Bank Syariah Mandiri (BSM), and PT Bank BNI Syariah (BNIS).

A merger, in this case, can be interpreted as a legal process to merge (fusion) a company (usually a less critical company) into a more critical company so that the merging company is dissolved. ${ }^{9}$ As a legal process, Bank Syariah Indonesia (BSI) merger is carried out through stages or processes based on several laws and regulations, namely regulations regarding limited liability companies, banking, taxation, and the capital market.

Article 28 paragraph (1) Act Number 10 of 1998 concerning Banking states that a bank merger, consolidation, and acquisition process must first obtain permission from the management of Bank Indonesia. Then referring to Bank Indonesia Regulation Number 19/13 / PBI / 2017 concerning Integrated

\footnotetext{
${ }^{6}$ Nurul Qomar, Muhammad Syarif, Dahran S Busthami, M. Kamal Hijaz, Aan Aswari, Hardianto Dj Sophisticated, \& Farah Syah Rezah, Metode Penelitian Hukum (Legal Research Methods), CV. Social Politic Genius (SIGn), Makassar, 2017, p. 5.

7I Made Pasek Diantha, Metodologi Penelitian Hukum Normatif Dalam Justifikasi Teori Hukum, Prenada Media, Jakarta, 2016, p. 13.

${ }^{8}$ Soekanto, Soerjono, Pengantar Penelitian Hukum, Universitas Indonesia, University of Indonesia, Jakarta, 1986, p. 132.

${ }^{9}$ Munir Fuady, Pengantar Hukum Bisnis Menata Bisnis Modern di Era Global, Citra Aditya Bhakti, Bandung, 2012, p. 91.
} 
Licensing Services related to Bank Operational Relationships with Bank Indonesia, the license is applied to banks that carry out corporate actions in the form of strategic and fundamental steps, including corporate merger activities. In obtaining the quo permit, Bank Syariah Indonesia (BSI) must go through a long stage of the merger process following the Financial Services Authority Regulation Number 41 / POJK.03 / 2019 concerning Merger, Consolidation, Takeover, Integration, and Conversion of Commercial Banks which in general are as follows:

a. Preparation and Compilation of Draft Merger (Article 8 and Article 9) ${ }^{10}$ states that in conducting the merger

The company management (directors) needs to take into account the performance of the companies. Information related to the company's performance in the form of financial audits and legal, due diligence from the process will determine whether a company can be merged or not. In the context of BSI, the merger has been prepared jointly by the directors of each company, namely PT Bank BRISyariah Tbk (BRIS), PT Bank Syariah Mandiri (BSM), and PT Bank BNI Syariah (BNIS), by making the Merger Draft document. In the design of the merger, there are various relevant data such as company information; general information regarding incorporation; the regulations that apply to the merger; due to the law of incorporation; the feasibility, risks, procedures, and potential challenges to the merger process; implementation of IDX regulations relating to mergers; information on incorporation and tax treatment; employee rights; shareholder rights; rights and obligations to third parties; etc.

b. Approval of the Board of Commissioners and Announcement of the Draft Merger in a Newspaper (Article 10)

In the event that a merger plan that the board of directors has prepared is submitted, the board of commissioners has the right to approve or reject the proposed merger. The merger plan that has the board of commissioners' approval has legal consequences for the board of directors, and the board of commissioners, both alone or collectively, are fully responsible for the correctness of all material information or facts in the draft merger. After obtaining approval from the board of commissioners, a summary of the draft merger is announced to the

\footnotetext{
${ }^{10}$ Supriono, Supriono, Ahmad Rodoni, Yacop Suparno, Hermida Hermida, Hilyatun Nafisah,

"Efficiency Performance Analysis of Panin Dubai Syariah Bank In Collecting and Distributing Third Party Funds Before and After Merger," I-Finance: A Research Journal on Islamic Finance, Volume 5

Number 1, 2019, p. 46-56.
} 
public through a daily newspaper, and submission of the statement and draft of the merger to the OJK. Submitting the statement and draft of the merger to OJK will later get the OJK's effective statement on the merger plan.

c. Approval of the Merger Plan at the General Meeting of Shareholders (Article 14)

Approval in the GMS is intended for three things, namely approval of the merger to be carried out, approval of the draft merger, and approval of the concept of the Deed of Merger or Merger. In the context of BSI, the EGMS (Extraordinary General Meeting of Shareholders) is held, preceded by submitting the EGMS agenda to the OJK. In the EGMS of PT Bank BRISyariah Tbk (BRIS), PT Bank Syariah Mandiri (BSM), and PT Bank BNI Syariah (BNIS), discussions were held regarding the draft merger, which had received approval from the board of commissioners. The shareholders of the three banks need to study and understand the draft merger as a consideration for them to make decisions at the EGM of each Bank. The results of the EGMS are submitted to the OJK as the regulator and the IDX and announced in an Indonesian language newspaper.

d. Submission of Merger Applications (Article 17)

At the latest 3 (three) working days after the EGMS decision approves the merger and immediately after being given a compelling statement of the merger plan by OJK, the board of directors then submits a merger application by submitting a registration statement to OJK accompanied by attachments to the draft merger and other supporting documents.

e. Merger Approval (Article 18)

The approval of the merger process is granted by the OJK in the form of approval of the merger application that has been submitted by the board of directors of the participating bank.

f. Merger Result Notification (Article 19)

Merger notification must be made by business actors to KPPU (Business Competition Supervisory Commission) and other institutions such as Bank Indonesia and the Indonesia Stock Exchange (IDX), which will each receive merger information and receive merger approval submission. The Ministry of Law and Human Rights will also accept the submission of the merger deed and amendments to the BSI articles of association. 


\section{B. The Effect of Merger of Indonesian Sharia Banks Related to the Development of Islamic Banking in Indonesia}

The development of the concept of Islamic banking in Indonesia in the last few decades has led to the emergence of many Islamic banks in Indonesia. National Islamic banks were born for the first time in 1991 with Bank Muamalat Indonesia (BMI) and officially began operating on May 1, 1992. ${ }^{11}$ After that, many other Islamic banks began to emerge, such as Bank Rakyat Indonesia Syariah, Bank Syariah Mandiri, Bank BNI Syariah, etc. In its development, the concept of Islamic banking institutions has become an alternative destination for people in Indonesia who want their funds to be stored and managed outside the existing conventional banking institutions.

The merger of three state-owned sharia banks, namely Bank BRI Syariah, Bank Mandiri Syariah, and Bank BNI Syariah, on February 1, 2021, has been the center of public attention in recent times. It is reasonable to discuss because the merger that occurred involved three large Islamic banks that already have many customers in Indonesia, and all three of them can be said to be leaders in the sharia banking business in Indonesia.

With the emergence of a new sizeable Islamic bank entity, namely Bank Syariah Indonesia (BSI), in this case, it will be a sign that, currently, Islamic banking has undergone many developments and changes since its inception. In 2020 alone, based on Bank Indonesia statistics in December 2020 , it shows an increase in the number of head offices by $1.7 \%$ and subbranch offices by $0.8 \%$ compared to the previous year. In addition, the growth of Islamic banks in Indonesia was also shown by the number of workers in Islamic banks, which increased by $2.64 \%$ from the previous year.

The establishment of the Indonesian Sharia Bank (BSI) in this regard can be said to be one of the efforts to strengthen the existing Islamic banking business strategy, which is expected to attract the interest of the Indonesian people to become customers of Islamic banks. Regarding the problem, there are still not many Indonesians who are customers of Islamic banks, one of which is because there is a phenomenon that occurs in Indonesian society where the majority cannot make choices to become customers at a sharia bank because they still doubt whether existing Islamic banks are pure and consistent in running their business based on sharia or just a business strategy of conventional banks by making their respective Islamic banks.

This assumption arose because many conventional banks then competed to make their respective Islamic banks participate in the Islamic

\footnotetext{
${ }^{11}$ Arif Pujiyono, "Posisi Prospek Bank Syariah Dalam Dunia Usaha Perbankan", Jurnal Dinamika Pembangunan (JDP), Volume 1 Number 1, 2004, p. 45-58.
} 
banking business, especially after the emergence of PBI No.8 / 3 / PBI / 2006, which later became the basis for conventional banks to form each of the Islamic business units. Doubts arise because conventional banks can form their respective Islamic business units using capital originating from usury. It then more or less affects the public, especially those who are Muslim, to become customers in Islamic banks. Consistency in the application of sharia principles, in the end, remains a significant problem, in addition to other factors such as poor sharia banking services also influence. ${ }^{12}$

Bank Syariah Indonesia (BSI), as a result of the merger of three large Islamic banks in Indonesia, in this case, is undoubtedly expected to prioritize consistency in running their business activities with the application of sharia principles because this is closely related to the religiosity of the majority of its customers. According to Dedi Sukamto \& Yulihardi ${ }^{13}$ Religiosity and service quality has a very significant influence on trust in Sharia Banks. It is necessary to pay attention to Indonesian Sharia Banks to continue to exist in Islamic banking.

The potential and market share of Islamic banking in Indonesia, in this case, is predicted to continue to grow from year to year, so that the Indonesian Sharia Bank (BSI), in this case, must undoubtedly have a positive impact on the world of Islamic banking in Indonesia. Seeing that Bank Syariah Indonesia (BSI) is a new bank that inherits all experience in Islamic banking from the banks that form it, it is hoped that it will be able to provide a new image for Islamic banking.

According to Salma Mahampang ${ }^{14}$ Sharia banks need to position themselves as banks that support each other with the support of the uniqueness of Islamic banks such as being transparent and fair for banks and customers, having competent human resources in finance which in turn will present a new branding for Islamic banks as more than just a bank. Usual, which in turn increases customer confidence in using Islamic banking products.

Another thing that Bank Syariah Indonesia (BSI) can do in helping the development of Islamic banking in Indonesia is to participate in building and developing a sharia-based digital economy. In this era of technology and digitalization, easy access for customers has taken many forms. One of the

\footnotetext{
${ }^{12}$ Amir Mu'allim, "Persepsi Masyarakat Terhadap Lembaga Keuangan Syariah", Al-Mawarid, Volume 10, 2003, p. 17-31.

${ }^{13}$ Dedi Sukamto, Yulihardi, "Analisis Peranan Religiusitas Terhadap Kepercayaan Kepada Perbankan Syariah", Magdis: Jurnal Kajian Ekonomi Islam, Volume 2, Number 2, 2017, p. 206-214.

${ }^{14}$ Salma Mahampang, "Globalisasi Pasar dan Kesiapan Perbankan Syariah Di Indonesia", Dinar: Jurnal Prodi Ekonomi Syariah, Volume 2, Number 2, 2019, p. 135-160.
} 
most visible is the ease of transactions with online payment / online payment. Online payment, in this case, makes it very easy for sellers and buyers to make transactions. With these various conveniences, the Islamic banking system has also started to apply it in the various sharia products offered. It is hoped that it will help boost the development of the Islamic economy in Indonesia.

With the principles of trust and justice, which are the advantages of the Islamic banking concept, this can be an essential factor in responding to the challenges of economic digitalization. Because digital economy users conduct online payment transaction activities, it is highly recommended to prioritize the principles of honesty and trust, which can guarantee the security of user data. Furthermore, Islamic banking institutions will undoubtedly be considered one of the leading choices for digital economy users in Indonesia to facilitate their economic activities.

\section{The merger of Indonesian Sharia Banks in terms of Business Competition Law}

Law no. 5 of 1999 has outlined the provisions regarding business competition in Indonesia. Based on Article 2 of a quo Law, it is stated that in carrying out their activities, business actors in Indonesia must be based on the principles of economic democracy by taking into account the interests of business actors and the public interest. ${ }^{15}$ In this case, business actors are prohibited from committing an act that may harm other business actors or the general public.

In general, a quo law prohibits every business actor from entering into agreements and business activities that can create monopolistic practices and/or unfair business competition. These agreements include oligopoly agreements, price-fixing agreements, territorial division agreements, boycott agreements, cartel agreements, trust agreements, oligopsony agreements, vertical integration agreements, closed agreements, and agreements with foreign parties that may result in monopolistic practices or unfair business competition. ${ }^{16}$ Meanwhile, several activities are prohibited, such as the prohibition of monopolistic practices, monopsony, market control, and

\footnotetext{
${ }^{15}$ Republic of Indonesia, Law no. 5 of 1999 concerning the Prohibition of Monopolistic Practices and Unfair Business Competition.

${ }^{16}$ Republic of Indonesia, Law no. 5 of 1999 concerning the Prohibition of Monopolistic Practices and Unfair Business Competition.
} 
conspiracy. ${ }^{17}$ The agreements and prohibited activities are solely intended to ensure that the business competition climate runs optimally as a contribution to the development of the national economy.

The term monopoly comes from the Greek monos polein, which means the seller himself. Monopoly means a market structure consisting of only one business actor or producer without direct or indirect competitors, including, in this case, actual or potential competitors whose products have close substitutes. ${ }^{18}$ In its development, the meaning of monopoly is no longer limited to controlling the market by only one business actor. Even though there are several business actors in a market, if there is one actor who controls a market, the business actor can be said to have a monopolistic position. ${ }^{19}$

The legislators do not prohibit the occurrence of monopoly, but what is prohibited is monopolistic practices. It occurs because of the monopoly of a business actor on certain goods and/or services; if it is carried out with fair competition, it shows the business actor's advantages, not an act that is detrimental to other parties. Meanwhile, monopolistic practices are prohibited because they lead to activities to control certain goods and/or services in improper ways and tend to cause losses to other business actors. In other words, a monopoly position does not necessarily violate Article 17 (regulating monopoly) of Law no. 5 of 1999,20 Based on Article 1, number 1 Law no. 5 of 1999, the monopoly is "Control over the production and or marketing of certain goods and or services by one business actor or a business group." Meanwhile, monopolistic practice is the "concentration of economic power by one or more business actors which results in the control of the production and or marketing of certain goods and or services to create unfair business competition and may be detrimental to the public interest." Of course, monopolistic practices are undesirable in the Indonesian economic system because the business actors concerned can control marketing and

\footnotetext{
${ }^{17}$ Republic of Indonesia, Law no. 5 of 1999 concerning the Prohibition of Monopolistic Practices and Unfair Business Competition.

${ }^{18}$ The Republic of Indonesia, Regulation of the Business Competition Supervisory Commission Number 11 of 2011 concerning Guidelines for Article 17 (Monopolistic Practices) Law Number 5 of 1999 concerning Prohibition of Monopoly Practices and Unfair Business Competition.

${ }^{19}$ The Republic of Indonesia, Regulation of the Business Competition Supervisory Commission Number 11 of 2011 concerning Guidelines for Article 17 (Monopolistic Practices) Law Number 5 of 1999 concerning Prohibition of Monopoly Practices and Unfair Business Competition.

${ }^{20}$ The Republic of Indonesia, Regulation of the Business Competition Supervisory Commission Number 11 of 2011 concerning Guidelines for Article 17 (Monopolistic Practices) Law Number 5 of 1999 concerning Prohibition of Monopoly Practices and Unfair Business Competition.
} 
determine prices. ${ }^{21}$ In addition, it is also capable of creating market barriers (entry barriers) for other business actors. Indicators regarding a market that can be said to have occurred monopoly occur in this case ${ }^{22}$ :

i. Business actors can influence the prices (price maker) of a product circulating in the market, while the buyer can only receive a predetermined price.

ii. Business actors have complete control over the market and do not need to make adjustments to competitors.

iii. The occurrence of an entry barrier for other business actors.

However, the prohibition on monopolistic practices is exempted for BUMN as referred to in Article 51 of Law no. 5 of 1999. The exception is reasonable considering that BUMN is a representation of state control over resources as referred to in Article 33 paragraph (2) of the 1945 Constitution of the Republic of Indonesia, which states that production branches which are essential to the state and which control the lives of many people are controlled by the state. For example, the state-owned company that has been granted monopoly rights by the state is PT PLN (Persero) which was initially granted under Law no. 15 of 1985 concerning Electricity. However, it was repealed by the enactment of Law no. 30 of 2009 concerning Electricity and strengthened again through the Decision of the Constitutional Court No. 111 / PUU-XIII / 2015.23

Several things, including can cause the concept of monopoly in economic activity ${ }^{24}$ :

a. The monopoly that occurs due to law (monopoly by law)

This type of monopoly gets its legitimacy through Article 33 of the 1945 Constitution of the Republic of Indonesia, which in principle can be exercised on the basis of protecting the livelihoods of many people so that the state can exercise control over specific resources for the benefit of the community. In addition, the monopoly that occurs as a result of obtaining intellectual property rights is also a monopoly that occurs due to law.

b. Monopoly born scientifically (monopoly by nature)

\footnotetext{
${ }^{21 Z u h r o ~ P u s p i t a s a r i, ~ " R e k o n s e p s i ~ P e n g e c u a l i a n ~ M o n o p o l i ~ Y a n g ~ D i s e l e n g g a r a k a n ~ O l e h ~ B a d a n ~ U s a h a ~}$ Milik Negara Dalam Hukum Persaingan Usaha di Indonesia", Jurnal Panorama Hukum, Volume 2 Number 2, 2017, p. 227-242.

${ }^{22}$ Michael L. Katz and Harvey S. Rosen in Putu Samawati, Monopoli BUMN Dalam Perspektif Persaingan Usaha, Tunggal Mandiri, Malang, 2018.

${ }^{23}$ Putu Samawati, Monopoli BUMN Dalam Perspektif Persaingan Usaha, Tunggal Mandiri, Malang, 2018. 24Johnny Ibrahim, Hukum Persaingan Usaha: filosofi, Teori, dan Implikasi Penerapannya di Indonesia, Bayumedia Publishing, Malang, 2009, p. 40-47.
} 
A monopoly that occurs as a result of controlling the company results from the professional ability to carry out company operations. In this case, the company can carry out activities or produce output effectively and efficiently so that it has a superior position and can dominate the market.

c. Monopoly issued by license due to collusion with the government (monopoly by license)

This type of monopoly occurs due to collusive practices carried out by business actors and government bureaucrats through licensing for economic activities in specific sectors.

d. Monopoly due to the market structure that occurs as a result of the behavior of this type of monopoly business actor occurs as a result of dishonest business practices committed between business actors.

Based on the four types of monopolies above, the types of monopoly points $\mathrm{c}$ and $\mathrm{d}$ are the types of prohibited monopolies because they can hinder the operation of the market economic system. ${ }^{25}$ (Putu Samawati, 2018). While the types of monopoly point $a$ and $b$, although justified, still have to be monitored so that economic concentration does not occur and is misused to gain maximum profit. ${ }^{26}$

In connection with corporate actions in mergers, consolidations, and acquisitions, business actors are also prohibited from carrying out such corporate actions, which may result in monopolistic practices and/or unfair business competition..$^{27}$ The meaning of 'monopolistic practices and/or unfair business competition occurs when a business actor carries out: prohibited agreements, prohibited activities, or abuse of dominant position. ${ }^{28}$ Monopolistic practice, in this case, is the primary focus to be emphasized in business competition law.

In this case, the (KPPU) plays its role. KPPU is an institution established by the government based on the mandate of Law No. 5 of 1999. ${ }^{29}$ This institution has the duty and authority in business competition

${ }^{25}$ Putu Samawati, Loc.Cit.

${ }^{26}$ Ibid.

${ }^{27}$ Republic of Indonesia, Government Regulation No. 57 of 2010 concerning Merger or Consolidation of Business Entities and Acquisition of Company Shares which May Result in Monopolistic Practices and Unfair Business Competition.

${ }^{28}$ Republic of Indonesia, Government Regulation No. 57 of 2010 concerning Merger or Consolidation of Business Entities and Acquisition of Company Shares which May Result in Monopolistic Practices and Unfair Business Competition.

${ }^{29}$ KPPU was formed based on Presidential Decree Number 75 of 1999 as amended by Presidential Regulation of the Republic of Indonesia Number 80 of 2008 concerning Amendments to Presidential Decree of the Republic of Indonesia Number 75 of 1999 concerning the Business Competition Supervisory Commission as a monopoly act. The total assets of both Sharia Commercial Banks and Sharia Business Units as of December 2020 were 593.9 trillion (OJK, 2020). Even if there was a 
supervision, one of which is related to the supervision of corporate actions in the form of mergers, acquisitions, or consolidations. The business actor has taken the corporate action within 30 days at the latest. It must notify the KPPU in writing. However, this provision only applies to business actors who carry out corporate actions with an asset value and a sales value of IDR 2,500,000,000,000.00 (two trillion five hundred billion rupiahs) and IDR $5,000,000,000,000.00$ (five trillion rupiahs), respectively. Meanwhile, for business actors in the banking sector, the asset value or sales value is required to be IDR 20,000,000,000,000.00 (twenty trillion rupiahs). After KPPU receives the notification, then KPPU will provide an assessment of the corporate action. Suppose later the assessment states a suspicion of monopolistic practices and/or unfair business competition. In that case, the KPPU will take action following the authorities granted by law, including imposing sanctions.

In proving the existence of an alleged violation of Article 17, KPPU uses a rule of reason approach, which is divided into several stages:

a. Defining the relevant market

b. Proof of the existence of a monopoly position in the relevant market

c. Identification of monopolistic practices carried out by business actors who have a monopolistic position

d. Identification and proof of negative impacts and parties affected by monopolistic practices.

In the context of the merger conducted by Bank Syariah Indonesia, as a result of the merger, it has assets worth IDR 215.6 trillion with a core capital of IDR 20.4 trillion. ${ }^{30}$ This figure, if a percentage, will be equal to more than $41 \%$ of the total national assets of Islamic banking. ${ }^{31}$ When associated with the restrictions in Article 17 of Law no. 5 of 1999, which stipulates that a business actor is considered to be conducting a monopoly if it controls a market share of more than $50 \%$, in this case, the merger carried out by the state-owned Islamic bank does not reach more than $50 \%$, so that normatively it cannot be categorized.

monopoly in the merger, a monopoly could still be justified because the monopoly was born naturally, based on professionalism, and was not carried out by conspiracy.

${ }^{30}$ Azizah Nur Alfi, "Aset Bank Merger Syariah BUMN Rp214,6 Triliun, Masuk Top 10 Bank

Terbesar", finansial.bisnis.com, March 11, 2021, accessed from https://finansial.bisnis.com/read/20201021/231/1307819/aset-bank-merger-syariah-bumn-rp2146triliun-masuk-top-10-bank-terbesar.

${ }^{31}$ Nabilah Anika, Nabila Indah Chairunnisa, \& Aditya Wahyu Saputro, Loc.Cit. 
The objective of the Indonesian Sharia Bank merger is to realize the competitiveness of the Islamic banking sector at both the national and international levels. ${ }^{32}$ It is motivated by the fact that the Islamic banking and financial industry has not significantly impacted the economy. ${ }^{33}$ Even though Indonesia is a considerable share of the Islamic financial market in terms of the Muslim population, which ranks first in the world, however, the State of Global Islamic Economic 2020 states that Indonesia is ranked fifth in the world in the Islamic finance industry, behind Malaysia, the United Arab Emirates, Bahrain, and Saudi Arabia.

In another perspective, the merger of the three Islamic banks will indirectly make it easier for the government to conduct supervision efficiently because it will only supervise one Islamic bank. ${ }^{34}$ In addition, the lecturer of Islamic Economic Studies at the University of Indonesia, Banjaran Surya Indrastomo, said that the merger could increase the competitiveness of Islamic banks because the merged bank would inherit positive things from the three banks. ${ }^{35}$ This competitiveness, especially in preparing for competition in the digital financial industry.

\section{CONCLUSION}

The merger of PT Bank BRI Syariah Tbk (BRIS), PT Bank Syariah Mandiri (BSM), and PT Bank BNI Syariah (BNIS) to become Bank Syariah Indonesia (BSI) is vital in terms of business competition law in order to create healthy business competition in banking services. The BSI merger review is intended to determine whether the corporate action is carried out in a healthy manner (fair) and does not have a monopolistic tendency. As the measure for reviewing the merger has been regulated in Article 17 and Article 28 of Law Number 5 of 1999 concerning the Prohibition of Monopolistic Practices and Unfair Business Competition, further analysis must be carried out on quo provisions based on a rule of reason legal approach and further analysis and continued from the economic approach (structure, conduct, and performance). The BSI merger does not contradict the law of business

\footnotetext{
32 M. Indra Kusumayudha, "Mega Merger Bank Syariah BUMN: Penerapan Prinsip Syariah Dalam Realitas Persaingan Perbankan Global", bahasan.id, March 14, 2021, accessed from https://bahasan.id/mega-merger-bank-syariah-bumn-penerapan-prinsip-syariah-dalam-realitaspersaingan-perbankan-global/.

${ }^{33} \mathrm{Ibid}$.

${ }^{34}$ Nabilah Anika, Nabila Indah Chairunnisa, \& Aditya Wahyu Saputro, Loc.Cit.

${ }^{35}$ Nida Sahara, "Merger Bank Syariah Milik BUMN Tingkatkan Daya Saing Industri", Investor.id, March 8, 2021, accessed from https://investor.id/finance/merger- bank-syariah-milik-bumntingkatkan-daya-saing-industri\#: :text=Dampak merger terhadap perkembangan ekonomi,menjadi pendorong pertumbuhan ekonomi nasional.\&text=Hal itu membuat bank syariah,memperbesar pangsa pasar keuang.
} 
competition because it does not meet the market share size of $50 \%$ to be said to be a monopoly practice based on Article 17 of a quo Law and does not result in a tendency to market structure, conduct, and performance of business actors which violates business competition law. Furthermore, the BSI merger process is also carried out in fairways based on Financial Services Authority Regulation Number 41 / POJK.03 / 2019 concerning Merger, Consolidation, Takeover, Integration, and Conversion of Commercial Banks. Because the BSI merger was carried out in a healthy manner (fair) and did not tend to practice monopoly, there was no detrimental impact of the merger on the banking business world. The BSI merger had a positive impact on the economic activities of Islamic banking in Indonesia. After the merger, BSI can become an effort to strengthen business strategies and competition instruments, which is manifested by a stronger preference for Indonesians who prioritize religiosity in the use of banking services. In addition, BSI can form a new image of Islamic banking and participate in building and developing a sharia-based digital economy, such as by providing online payment services (online payment).

\section{DECLARATION OF CONFLICTION INTERESTS}

None

\section{FUNDING INFORMATION}

None

\section{ACKNOWLEDGEMENT}

Praise be to Allah SWT for His will and blessing that this research can be completed properly. We also express our gratitude to all those who have played a role in completing this research. We realize that this research will not be adequately completed without prayers, support, and encouragement from various parties.

\section{REFERENCES}

Alfi, A. N. (2021). “Aset Bank Merger Syariah BUMN Rp214,6 Triliun, Masuk Top 10 Bank Terbesar". Finansial.bisnis.com, March 11, 2021, accessed from https://finansial.bisnis.com/read/20201021/231/1307819/aset-bankmerger-syariah-bumn-rp2146-triliun-masuk-top-10-bank-terbesar.

Anika, N., Chairunnisa, N. I., \& Saputro, A. W. (2021). Potensi Praktik Monopoli Dalam Merger Bank Syariah Indonesia: Tinjauan Hukum 
Ekonomi Islam dan Hukum Larangan Monopoli, Rewang Rencang: Jurnal Hukum Lex Generalis, 2(2), 174-194.

Anshori, A. G. (2008). Sejarah Perkembangan Hukum Perbankan Syariah di Indonesia dan Implikasinya Bagi Praktik Perbankan Nasional. Jurnal Hukum Islam La Riba, 2 (2), 159-172.

Barus, C. (2020). "Jumlah Penduduk Muslim Indonesia Meningkat,PowerCommerce Asia Tangkap Peluang, Luncurkan Halal Plaza". industricoid., May 16, 2021, accessed from https://www.industry.co.id/read/65748/jotal-penduduk-muslimindonesia-men Increase-powercommerce-asia-tangkap-peluang-1 Launch-halal-plaza.

Diantha, I. M. P. (2016). Metodologi Penelitian Hukum Normatif Dalam Justifikasi Teori Hukum. Jakarta: Prenada Media.

Fuady, M. (2012). Pengantar Hukum Bisnis Menata Bisnis Modern di Era Global. Bandung: Citra Aditya Bakti.

Ibrahim, J. (2009). Hukum Persaingan Usaha: filosofi, Teori, dan Implikasi Penerapannya di Indonesia. Malang: Bayumedia Publishing.

Iskamto, D. \& Yulihardi (2017). Analisis Peranan Religiusitas Terhadap Kepercayaan Kepada Perbankan Syariah. Magdis: Jurnal Kajian Ekonomi Islam, 2(2), 206-214.

Kusumayudha, M. I. (2020). “Mega Merger Bank Syariah BUMN: Penerapan Prinsip Syariah Dalam Realitas Persaingan Perbankan Global". Bahasan.id, March 14, 2021, accessed from https://bahasan.id/megamerger-bank-syariah-bumn- implementation-sharia-principles-inreality-competition-global-banking /.

Mahmudah, S. (2019). Globalisasi Pasar dan Kesiapan Perbankan Syariah Di Indonesia. Dinar: Jurnal Prodi Ekonomi Syariah, 2(2), 135-160.

Mu'allim, A. (2003). Persepsi Masyarakat Terhadap Lembaga Keuangan Syariah. Al-Mawarid Edisi X, 17-31.

OJK. (2021). Statistik Perbankan Syariah Februari 2021. Jakarta: Financial Services Authority.

Pujiyono, A. (2004). Posisi Prospek Bank Syariah Dalam Dunia Usaha Perbankan. Jurnal Dinamika Pembangunan (JDP), 1(1), 45-58.

Puspitasari, Z. (2017). Rekonsepsi Pengecualian Monopoli Yang Diselenggarakan Oleh Badan Usaha Milik Negara Dalam Hukum Persaingan Usaha di Indonesia. Jurnal Panorama Hukum, 2(2), 227-242.

Qamar, N., Syarif, M., Busthami, D. S., Hidjaz, MK, Aswari, A., Dj Sophisticated, H., \& Rezah, F. S. (2017). Metode Penelitian Hukum (Legal Research Methods). Makassar: CV. Social Politic Genius (SIGn). 
Sahara, N. (2020). “Merger Bank Syariah Milik BUMN Tingkatkan Daya Saing Industri". Investor.id, March 8, 2021, accessed from https://investor.id/finance/merger- bank-syariah-milik-bumntingkatkan-daya-saing-industri\#: :text=Dampak merger terhadap perkembangan ekonomi,menjadi pendorong pertumbuhan ekonomi nasional.\&text=Hal itu membuat bank syariah,memperbesar pangsa pasar keuang.

Samawati, P. (2018). Monopoli BUMN Dalam Perspektif Persaingan Usaha. Malang: Single Independent.

Soenjoto, W. P. P. (2018). Tantangan Bank Syariah Di Era Globalisasi. el Barka: Journal of Islamic and Business, 1(1), 79-103.

Soerjono, S. (1986). Pengantar Penelitian Hukum. Jakarta: University of Indonesia.

Supriyono, S., Rodoni, A., Suparno, Y., Hermadi, H., \& Nafisah, H. (2019). Efficiency Performance Analysis of Panin Dubai Syariah Bank In Collecting and Distributing Third Party Funds Before and After Merger. I-Finance: A Research Journal on Islamic Finance, 5(1), 46-56.

Syukron, A. (2013). Dinamika Perkembangan Perbankan Syariah Di Indonesia. Jurnal Ekonomi dan Hukum Islam STAI Darul Ulum Banyuwangi, 3(2), 28-53. 


\section{ABOUT AUTHOR(S)}

Shahyb Handyanto, born in Batang, October 28, 1999 is a student of the Faculty of Law Gadjah Mada University (FH UGM) with a concentration in business law. Active in various activities such as being the Vice Director of Student Development Business Law Community, research assistant, and assistant professor. In addition, he is also active in participating in essay competitions, contract drafting, and research activities.

Monita Sri Astuti, born in Kulon Progo August 12, 1998, is a student of Faculty of Law UGM. Actively joins various organizations and communities on campus, including DEMA Justicia FH UGM, Muslim Family FH UGM, and the Satria Paramartha Motu Court Community.

Kevin Surya Ajiputra, is a student of Faculty of Law UGM. Active on campus by participating in various organizations and activities including the administrators of the Muslim Family of FH UGM and Research Assistant from Dr. Dinarjati Eka Puspitasari, SH, M. Hum. for lecturer research with the title "A Study of Health Center Medical Waste Management as an Effort to Fulfill Environmental Health Quality in the City of Yogyakarta" in 2019. 